\title{
Cinematic Architecture and Place Perception: A Study on Wes Anderson's Film the Grand Budapest Hotel (2014)
}

\author{
Alp Karaca \\ Faculty of Fine Arts, American University of Cyprus \\ PO box 99010, Nicosia, Cyprus \\ E-mail: a.karaca@auc.edu.tr \\ Pelin Agocuk \\ Faculty of Fine Arts, American University of Cyprus \\ PO box 99010, Nicosia, Cyprus \\ E-mail: p.agocuk@auc.edu.tr
}

\begin{abstract}
Although there are many differences and innovations in creating place in cinema, virtual spaces can be created as well as using real architectural-urban or physical environments. The perception of time, which is an important element that improves the narrative language of cinema, is related to creating an architectural and spatial image. Cinema and architecture, as two separate disciplines, are not independent from each other in terms of creating a cinematographic place perception. Therefore, the importance of cinema and architecture interaction in creating cinematic place is discussed in this study. The aim of the study is to examine the relationship between architecture and cinema, which are two separate art branches, through the "perception of place" and to explain the cinematographic effects of architecture through the example of Wes Anderson's "The Grand Budapest Hotel".

In both areas, it has been tried to explain to what extent the place's important elements in terms of time, movement, light, color and shadow reflect the reality. While "design" is an important issue in fictional places, it is also necessary in terms of creating a space perception. In this study, it is aimed to analyze the film structure with architectural semiotic approach, especially the role of architectural and space usage in cinema, by emphasizing the processes and reference points of the interaction between both disciplines. According to the case of Wes Anderson's The Grand Budapest Hotel (2014), the specific spaces of the film, the perception of space and the role of cinematographic space designs are discussed. In line with this information, subjects such as space design and spatial density in cinema, space, balance, harmony and symmetry in architecture and cinema, construction process and its effects in cinema and the perception of space in cinema were examined. The architectural structure and the suitability of the space design to the story are also discussed in the film. The film, which is considered as an exemplary analysis within the scope of the research, was chosen as a purposeful sampling because it is an example of especially the relationship between harmony and balance in cinema and the relationship between cinema and architecture explore and sets an example.
\end{abstract}

Keywords: cinema and architecture, perception of place, place design of cinematographic

DOI: $10.7176 / J S T R / 7-04-08$

\section{Sinemasal Mimari Ve Mekân Algısı: The Grand Budapest Hotel (2014) Filmi Üzerine Bir İnceleme}

Öz

$\mathrm{Bu}$ çalışmada, sinema ve mimarlık temelinde mekân olgusu sorgulanarak, mekânların sinematik temsiliyle ilgili değerlendirmeleri ele alınmıştır. Sinema ve mimarlığın sinematografik mekân algısı yaratma açısından birbirinden bağımsız olmadığından hareketle, sinemada mekân tasarımı ve mekânsal yoğunluk, mimari ve sinemada mekân, denge, uyum ve simetri, sinemada mekânsal inşa süreci konuları tartışmaya açılmıştır. Çalışmada, mimarlık ve sinema arasındaki ilişki 'mekân algısı'

76 | P a g e

www.iiste.org 
üzerinden incelenerek mimarlığın sinematografik açıdan etkileri Wes Anderson'ın The Grand Budapest Hotel (2014) örneği üzerinden açıklanmaya çalışılmıştır. Çalışmanın amacı disiplinlerarası yaklaşımla, mimarlık ve sinema arasındaki ilişkinin 'mekân algısı' üzerinden incelenmesi ve mimarinin sinematografik etkilerinin, Wes Anderson'un The Grand Budapest Hotel (2014) filmi örneği üzerinden açıklanmasıdır. Çalışmanın evrenini auteur olarak kabul edilen yönetmenlerin 2010 yılı sonrası çekilen filmlerinin tamamı oluştururken, çalışmada filmlerinde mekâna yönelik simetri ve uyum ile sinema ve mimari ilişkisinin en fazla göze çarptığı The Grand Budapest Hotel (2014) filmi amaçlı örneklem tekniği kullanılarak seçilmiştir. Çalışmada nitel araştırma yöntemlerinden film çözümlemesi tekniği kullanılmıștır. Çalışmada sinema ve mimarlık etkileşimi temelinde, sinematografik mekân analizleri ve mimari mekânların sinematik temsili ile ilgili değerlendirmeler ortaya konulmuştur. Çalışma kapsamında, filmsel yapı çözümlemesi ile sinema ve mimarlık arasındaki etkileşimin süreçleri ve referans noktaları vurgulanarak, sinemada mimarlık ve mekân kullanım biçimlerinin rolü, sinematografik mekân analizlerinin anlamsal çeşitliliklerini ortaya koyabilmek amacıyla, göstergebilimsel yaklaşım yöntem olarak kullanılmıştır.

Anahtar kelimeler: sinema, mimari, mekân algısı, sinematografi, mekân tasarımı

\section{Giriş}

20. yüzyılın en önemli buluşlarından biri olan sinema tarihsel, toplumsal, siyasal ve ekonomik gelişmelere paralel olarak gelişimini sürdüren ve özellikle teknolojik gelişmelerle birlikte sürekli kendini yenileyen bir sanat dalıdır. Sinemanın gerçekliği yeniden inşa ettiği düşünüldüğünde, dönemin özelliklerini tarihsel ve toplumsal bağlamda yansıttığı ve teknolojinin sunduğu imkânlarla gelecek tasavvurunu zamansal ve mekânsal birliktelikle sunabildiği ifade edilebilir.

$\mathrm{Bu}$ çalışma, modernitenin de etkisiyle şekillenen mekân algısının sinematografik olarak nasıl aktarıldığına dair bir incelemeyi içermektedir. Mimarlık ve sinema temelinde, mekân olgusunun sinematik temsillerine odaklanan çalışmada, mekânsal analizler göstergebilim yaklaşımla tartışmaya açılmıştır. Modernitenin şekillendirdiği mimari yapılar ve mekan algısının sinemada, hem filmin tematik yapısının, hem de stilistik (biçimsel) yapısının bir metaforu olduğu düşünülmektedir.

Sinemasal mekânlar, kültürel ve sanatsal açıdan tarihsel olarak soyutlanmış bir gerçeklik ve yeni bir dünya inşası sunabilmektedir.

Mekân algısı insanın geçmişle olan bağıyla ve anılarıyla ilgilidir. Anımsanan şeyler mekânlara bağlı olarak gelişir ve hafiza mekânları hem hatırlamaya yönelik işaretler hem de geçmişle kurulan bağ arasında bir köprü görevi görerek aidiyet duygusunun gelişmesi yönünde bir işlev görür. Sinema bu noktada mimari olarak tasarlanan mekânları insanların gerçek görsel deneyimlerine en yakın haliyle inşa eder. Mekânsal olarak tasarlanan sinematografik tasarım ve kompozisyon gerçekliğin inşa edilmesi açısından izleyicide zihinsel olarak bağ kurmasını ve aidiyet duygusunu yaratması bakımından önemlidir. Sinemada aynı zamanda geleceğin inşa sürecini yansıtabilmek için kendi sinematik evreninde sanal mekânlar yaratılır. Toplumlar tarafından deneyimlenmemiş ve tanımlanmamış sanal mekânları tasarımında da mimarlık ve sinema etkileşimi etkisini ön plana çıkarır.

$\mathrm{Bu}$ çalışmada, disiplinlerarası yaklaşımla sinema ve mimarlık etkileşimi mekân algısı ekseninde sinematografik unsurlar göz önünde bulundurularak incelenmiştir. Sinema ve mimarlık birbirinden bağımsız ve ayrı olarak değerlendirilemeyeceği gibi, zaman ve mekân bütünlüğü açısından da etkileşimi kaçınılmazdır. Bu bağlamda, iki alan arasındaki etkileşim, mekân algısının geçmişle olan bağı, mimari kompozisyon ve sinematografik mekân tasarımı filmlerde yansıtılan tarihsel süreçlerle izleyici arasında bir yakınlık kurulmasına yardımcı olur. Sinema ve mimari arasındaki etkileşimin referans noktaları mekânın kurgusal açıdan önemli olan öğeleri, mekân ve zaman bütünlüğü, hareket, 1şık, renk ve gölge ilişkisi konularıdır. Dolayısıyla çalışmada ele alınacak konular, sinemasal mimari ve kompozisyon açısından ön plana çıkan Wes Anderson'ın The Grand Budapest Hotel (2014) filmi üzerinden açıklanmıştır. Filme özgü mekân ve mekân algısının sinematografik anlatıdaki rolü ele alınacaktır. Çalışmanın kavramsal çerçevesini sinema ve mimari arasındaki etkileşim oluşturmakla birlikte, sinema tarihinde yer alan filmlerde yaratılan mekân algısı tarihsel ve toplumsal bağlamda ele alınmaya çalışılmıştır.

\section{Sinema ve Mimari: Sinemasal Mekânlar}

Sinema her sanat dalıyla etkileşim içinde olan modern gösteri sanatlarından biridir. Özellikle sinema ve mimari ilişkisi, mekân tasarımı ve izleyicide yaratılan mekân algısı gerçeklikle bağ kurulabilmesi

77 | P a g e

www.iiste.org 
bakımından önemlidir. Filmler herhangi bir durumu yansıtmaktan çok o durumun tasarlanan belli bir biçimini oluşturmak için seçilen ve birleştirilen temsili öğeler yoluyla birtakım tezler ileri sürerler ve bunu yaparken de, izleyiciye belli bir konumu veya bakış açısını telkin ederler (Ryan ve Kellner, 2010, s. 18). Bu temsili öğelerin en önemlisi ise izleyiciye filmde inşa edilen toplumsal gerçekliği yansıtabilmek için oluşturulan sinemasal mekânlardır.

Filmler toplumsal gerçekliği yansıtan, meşrulaştıran ve aynı zamanda toplumun kendini yeniden üretebilmesi için ipuçları barındırır (Zizek, s. 11-15 2010; Öztürk, 2012). Sinemanın toplumsal gerçekliği yansıttığı düşünüldüğünde, bir yandan geçmişi yeniden inşa ederken, diğer yandan da geleceğin inşası konusunda toplumların kendini yeniden üretebilmesi için yol gösterici olurlar. Dolayısıyla filmler hem geçmiş hem de gelecek arasında bir köprü görevi görerek, hızla modernleşen dünyada toplumları geleceğin yeniden inşası sürecine hazırlarlar.

Sinema kitle kültürü toplumunda, kitlesel üretim çağında, kitlesel örgütlenme döneminde ve toplumların kentsel hayata hızla geçtiği evreye uyan kültürel bir edim olduğu gibi, kentsel gündelik hayatta ihtiyaç duyulan estetik bir araçtır (Öztürk, 2007, s. 16). Sinema sanatı tıpkı mimarlıkta olduğu gibi modernleşme sürecinde toplumların kendini yeniden üretebilmesine katkıda bulunurlar.

Pallasmaa’ye göre (2008) Mimarlık ve sinema, yaşamın çok yönlü görüntülerini oluşturarak onlara aracılık etmeleri nedeniyle birbirleriyle sıkı bir ilişki içerisindedirler. Binalar ve kentler, kültürün ve belirli yaşam biçimlerinin görüntülerini yaratarak korurlar. Sinema, hem içinde bulunduğu dönemin hem de yansıttığı ve yarattığı zamanın kültürel arkeolojisini ortaya çıkarır. Dolayısıyla sinema ve mimarlık var olan mekânın özünü ve boyutlarını tanımlarken aynı zamanda, yaşamın içinde deneysel sahneler yaratırlar.

Sinema bir yandan izleyicinin aşina olduğu, tanımlanmış mimari mekânları yeniden üretirken, diğer taraftan da daha önce deneyimlemediği ve tanımlanmamış mimari mekanları yaratma özelliğine sahiptir. Bu yaratım sürecinde sinema ve mimarlık iletişim ve etkileşim içindedir. Tanyeli (2001, s. 66) mimarlık ve sinema ilişkisini belli kriterler ve sınıflandırma ile ele alır. Bu sınıflandırmaya göre; sinema inşa edilmemiş ve gerçeklik düzleminde var olmayan bir sanal mimarlık alanı tanımlaması, sinemanın gerçek mimari mekânları kendi sanal evreninde yeniden üretmesi ve son olarak da sinemanın kendi kurgusu (olay örgüsü) içinde bir mimariyi veya mimari etkinliği ele almasıdır.

1920'lerin Rus filmleri, propaganda mesajlarını iletmenin ötesinde, duygusal ve uzamsal muazzamlıkları nedeniyle, algılanabilmeleri için sinematik muameleye iki misli ihtiyaç duyan gerçek kitlelerin kriz üstü ayaklanmalarını iletirler. Sinema altüst olan tanığı bilinçli bir gözlemciye dönüştürmeyi amaçlar (Kracauer, 2015, 147). Sinemanın gerçek mimari mekanları kendi sinematik evreninde yeniden ürettiği düşünüldüğünde, sanayileşme ve modernleşmeye hızla ayak uydurmak isteyen Sovyetler'de, biçimci kuramın etkisiyle geçmişin kültürel mirasının ve yaşanan olayların filmler aracılığıyla, mekânsal alg1 yaratılarak yeniden inşa edildiği söylenebilir. Einsenstein'ın Potemkin Zırhlısi (1925) filmi bu konuya en iyi örneklerden biridir.

Alman dişavurumcu akımın bir örneği olan fütüristik distopya Metropolis (1927, Fritz Lang), filmi, yine eksprestyonist akımın en önemli filmlerinden Dr. Calligari'nin Muayenehanesi (Robert Wiene, 1920) gibi filmler alışılmamış dekorları, izleyiciyi alt üst eden mimari tasarımı ile inşa edilmemiş ve gerçeklik düzleminde var olmayan bir sanal mimarlık alanı tanımlamasına örnektir. 2001: A Space Oddissey (1968, Stanley Kubrick) filmi hem evrimleşme tarihi ile geçmişin yeniden tasavvuru ve sanal mekan tasarımıyla inşa edilen gerçeklik, hem de geleceğin inşası ve yansıtılan sanal gerçeklik ve sanal mekan tasarımı açısından sinema tarihinde en önemli fimlerden biridir. Black Panther, Blade Runner: 2049 (2018, Ryan Coogler) filmi ise Marvel'in sinematik evrenini yansitan süper kahraman filmi olmasından öte, inşa edilmemiş ve gerçeklik düzleminde var olmayan bir sanal mimarlık alanı sunması konusuna örnektir denilebilir. Rus Hazine Sandı̆̆ (2002, Aleksandr Sokurov) ise gerçek mimari bir yapıyı ele alarak 400 yıllık Rus tarihine 1şık tutan ve çekim teknikleri açısından sinema tarihine geçen önemli bir filmdir.

\subsection{Sinemada Mekân Algısı ve Aidiyetlik Duygusu}

Sinemada inşa edilen zaman ve mekân algısı gerçeklikle büyük ölçüde benzerlik taşımaktadır. Zamana ve mekâna bağlılık ve aidiyet duygusu sinemada, insan deneyimlerini içeren zamanı ve mekanı temsil eder. Ricoeur'a göre (2017, p. 59-60) anımsanan şeyler içten içe mekânlara bağlıdır ve aslında "hafıza mekânları" fenomeni, tarihsel bilginin göndergesine dönüşmeden önce bu ilksel düzeyde oluşur. Bu hafıza mekânları hem hatırlamaya yönelik işaretler, hem gitgide zayıflayan hafizaya, hem de unutuşa karşı verilen savaşta yardımcı kuvvetler olarak ölü hafızanın yerine geçmiş yedek hafızalardır. Ona göre (2017) mekânlar tıpkı yazıtlar, anıtlar gibi potansiyel belgeler olarak kalır, sadece sözel olarak

78 | $\mathrm{P}$ a g e

www.iiste.org 
aktarılan anılar ise sözler gibi uçup gider.

Mekân algısı geçmişle olan bağın kurulmasının yanı sıra insanların aidiyet duygusunu da pekiştiren önemli konulardır. Mekâna yönelik algı, insanların yaşam deneyimleriyle ilişkilidir. Çevre ile dünyayı algılama ve yorumlama becerisi mekânsal algı ile gerçekleşmekte ve böylece uyum sağlama süreci kolaylaşmaktadır. Pallasma (2008) "Sinema ve Mimarlık: Yaşayan Mekân” adlı çalışmasında, bireyin, zihinsel ve bedensel olarak ayrı ve tamamen tarafsız bir dünyada yaşamadığını, içinde deneyimlenen, hatırlanan ve hayal edilen kadar geçmişin, şimdinin ve geleceğin de ayrılmaz bir şekilde birbirinin içine geçtiği zihinsel dünyalarda yaşadığını ifade eder. Ona göre (2008), mimarlığı ve sinemayı deneyimleme biçimi, sabit, sınırları olmayan zihinsel mekânda özdeş bir hale gelir ve mimarlık sanatında bile, zihinsel bir görüntü mimarın deneysel dünyasından gözlemcinin zihinsel dünyasına aktarılır. Dolayısıyla her iki sanat dalı da yaşamdan kareler, insan etkileşimleri ve dünyayı algılamanın yollarını betimler.

Öztürk’e (2012, s. 27) göre mekân, sadece toplumsal ilişkilerin pasif yansıtıcısı değildir, aynı zamanda toplumsal ilişkilere de etki eder ve bu etki iki yönlü olabilir: ya var olan ilişkileri güçlendirir, ya da tam tersi zayıflatır veya ortadan kalkmasına neden olur. İşte bu yönüyle mekân diyalektik bir boyuta sahiptir. Sinemada mekân algısı ve mekân tasarımı inşa edilen gerçeklik açısından bakıldığında, izleyici deneyimi için diğer unsurlardan daha önemlidir. Dolayısıyla izleyicinin sinemasal mekânlar aracılığıyla bağ kurduğu hikâyede mekâna yönelik olarak, ya aidiyet duygusunu pekiştirir ya da tam tersi biçimde sanal olarak deneyimlediği mekana yabancılaşmasına neden olabilir.

Aslında sinemasal mekânlar filmlerde, deneyimlediğimiz mekânları içermesinden öte, rüyalarımıza benzer şekilde mekânları zihinsel olarak deneyimleme firsatı verir. Sinema ve mimarlı̆̆ı ortak konusu mekân tasarımı, bireyin gerçek veya hayal ürünü kişisel deneyimlerini içerir. Sinema imgeleri sosyal hayatımızı etkiler ve bu, filmlerle tanımlanmış zaman ve mekân kavramlarının insan zihninde ki görsel hafıza tarafindan deneyimlenmesi ile gerçekleşir (Akt, Beşışık,2013, s. 13).

Sinema ve mimarlık etkileşimi, doğal bir sonuç olarak mimarlığın farklı boyutlarda geri besleme sağlamasını beraberinde getirmiştir. Dolayısıyla her filmin gerek görsel, gerek düşünsel olarak mimarlığa katkı sağlayacak bilgiyi içinde barındırdığı ve mekânın hem tasarlanması hem de algılanması konusunda tartışma zemini oluşturduğu söylenebilir (Beşgen ve Köseoğlu, 2019, s.31). Sinema ve mimarlık birbirinden etkilenen, özellikle modern dünyaya ait mekânlar tasarlamaya yönelik arayış içinde olan iki ayrı sanat dalıdır. Mimarlık ve sinema, yaşamın çok yönlü görüntülerini oluşturmaları ve bu oluşuma aracılık etmeleri nedeniyle birbirleriyle sıkı bir ilişki içerisindedir (Ersoy, 2010, s. 8).

\section{Yöntem}

Çalışmada, mimarlık ve sinema arasındaki ilişki 'mekân algısı' üzerinden incelenerek mimarlığın sinematografik açıdan etkileri Wes Anderson'ın The Grand Budapest Hotel (2014) örneği üzerinden açıklanmıştır. İki disiplin arasındaki etkileşimin süreçleri ve referans noktaları vurgulanarak, sinemada mimari ve mekân kullanım biçimlerinin rolü, mimari göstergebilimsel yaklaşımla filmsel yapı çözümlemesi yapılarak değerlendirilmiştir. Araştırma kapsamında örnek çözümleme olarak ele alınan film, sinema ile mimarlık ilişkisinin ön plana çıkması ve bu alana örnek oluşturması nedeniyle amaçlı örneklem yoluyla seçilmiştir. Çalışmanın amacı, mimarlık ve sinema arasındaki etkileşimi, 'mekân algısı' üzerinden incelemek ve mimarinin sinematografik etkilerini, Wes Anderson'un The Grand Budapest Hotel (2014) filmi örneği üzerinden açıklamaktır. Bu bilgiler 1şığında çalışmanın literatüre özgün bir değer ve katkı koyacağı düşünülmektedir.

Her iki alanda mekânın kurgusal açıdan önemli olan öğeleri zaman, hareket, 1şık, renk ve gölge ilişkisi bakımından gerçeği ne derece yansıttığı açıklanmaya çalışılmıştır. Kurgusal mekânlarda "tasarım" önemli bir konu iken mekân algısı yaratma açısından da gereklidir. Bu bilgiler doğrultusunda, Wes Anderson'un The Grand Budapest Hotel (2014) filmi örneği üzerinden, filme özgü mekân ve mekân algısı ile sinematografik anlatıdaki rolünün ele alındığı çalışma, aşağıdaki temel başlıklar esas alınarak ele alınmıştır.

- Sinemada mekânsal yoğunluk ve mekân kullanımının sinematografik açıdan yarattığı mekan algis1

- Sinemada mekân yaratma ve mekân algısı öyküye uygun olarak tasarlanıp tasarlanmadığı

- Mimari ve sinemasal mekânda denge, uyum ve simetri

- Sinemada mekânsal inşa süreci ve etkileri

$\mathrm{Bu}$ film sinemada özellikle uyum ve denge ilişkisi bakımından mimarlık ve sinema ilişkisini ortaya çıkaran unsurlara önemli bir örnek teşkil etmesi bakımından inceleme konusu olarak seçilmiştir.

79 | $\mathrm{P}$ a g e

www.iiste.org 


\section{Bulgular}

4.1 Sinematografik Mekân Algısı: The Grand Budapest Hotel ( Was Anderson, 2014)

Ünlü yöntemen Wes Anderson'ın yönetmenliğini yapmış olduğu masalsı film The Grand Budapest Hotel (2014) izleyiciyi farklı mekânlar arasında geçişler, kullanılan güçlü renk paleti seçenekleri, iyi ve kötüyü ayrıştıran tonlama, mekan tasarımları ve derinlik hissi veren sahneleri ile adeta bir görsel şölen yaşatmaktadır. Hem farklı tasarımsal teknikler kullanılması, hem de renklerdeki değişimlerle birlikte 1932 yılı oteli ile 1968 yılı oteli arasındaki vurgu ve farklılıklar güçlendirilmiş, filmde geçen konularda "her şey yolunda" veya "her şey yolunda değil" izlenimi bu farklılıklarla izleyiciye aktarılmıştır. Böylelikle izleyici kendisini filmin bir parçası, birebir olayları yaşayan özne haline getirmiş ve filmin etkisi bu yöntemle artmıştır. Mekansal algıyı artırmak adına perspektif tekniği ile birçok sahneye derinlik katılmış, böylelikle mekânsal algıyı artırarak, daha ferah ve büyük mekanlar olduğu izlenimi yaratılmıştır ( Bkz. Görsel 1 ).

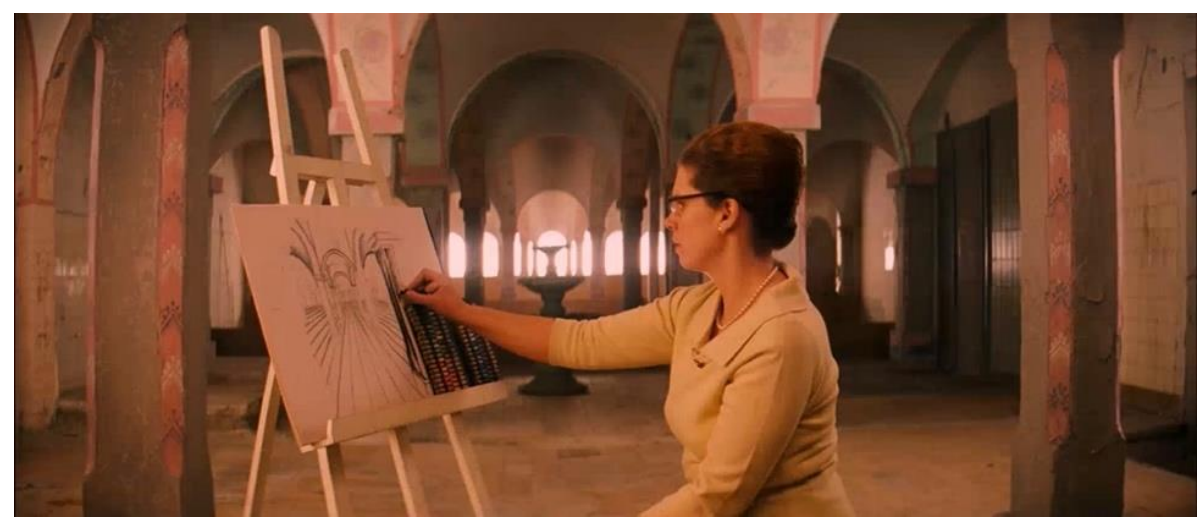

Görsel 1.

1932 ile 1968 yılları arasında otelin iç ve dış mekânlarında, genellikle kıyaslamalar yapılmıştır. 1932 yılında geçen otel sahneleri daha kalabalık, daha canlı ve hareketli bir dönemi temsil ederken, 68 yılında geçen sahnelerde artık kaderine terk edilmiş, çalışmayan, popülerliğini yitirmiş ve oldukça hareketsiz bir otel sahnelenmiştir. Yönetmen iki ayrı dönemi özellikle kullandığı mekân tasarımıyla kıyaslamış, sahneler ve çekimlerde kullandığı tekniklerle de güçlendirmiştir. Kıyaslama yöntemi simetrik - asimetrik sahneler, renk konusundaki canlı ton -koyu ton, kalabalık - kalabalık olmayan sahneler, daha zengin gösteren dönemsel tasarımlar - düz iddiasız sıradan tasarımlar gibi zıtlıklar ve tekniklerle ayrım daha da belirginleştirilmiştir. Özellikle 1938 ile 1962 dönemine ait otelin tasarımları oldukça farklıdır. 1938 yılındaki otelin, gerek dış cephesi gerekse iç mekânlarına yansıyan "Art Nouveou" dönemine ait çizgiler dikkat çekmektedir ( Bkz. Görsel 2 ve 3 ).

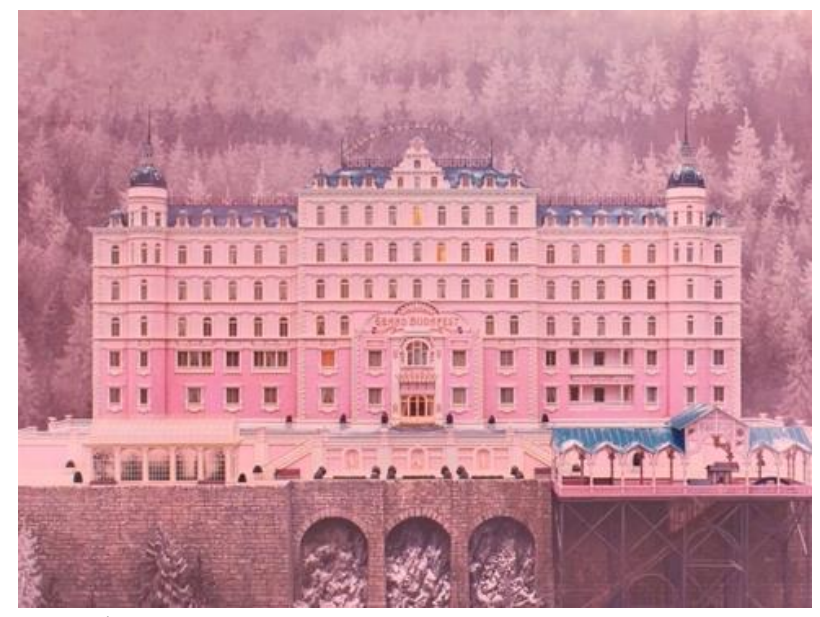

Görsel 2. 


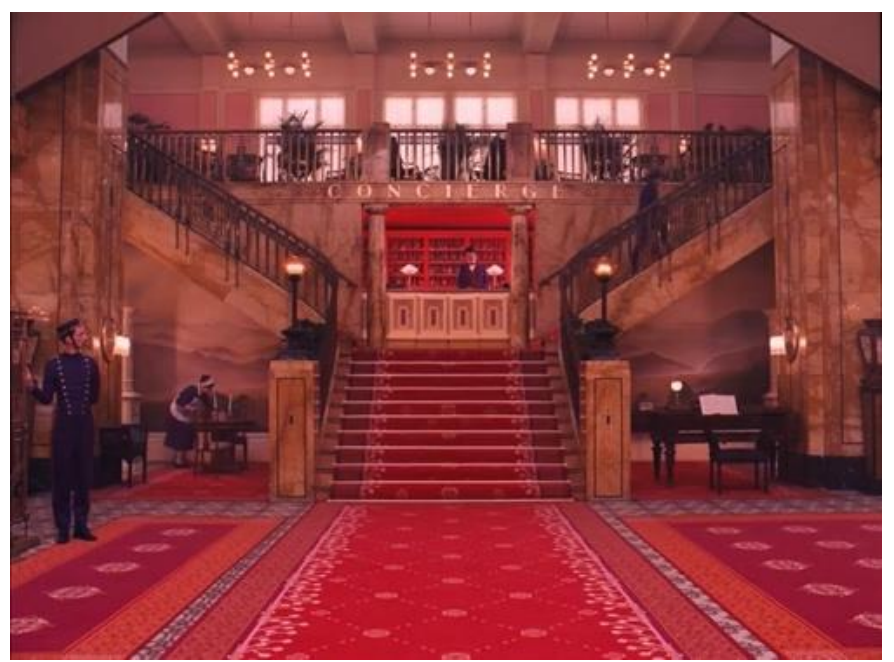

\section{Görsel 3.}

Bazı sahnelerde, kamera açısı kullanılarak mekanlar içerisine izleyici de dahil edilmekte ve izleyicinin tıpkı filmdeki bir karakter gibi hikayeyle ve karakterlerle özdeşleşmektedir (Bkz. Görsel 4.). Sinemanın ve mimarlığın gerçekleştirmeyi hedeflediği yaşayan mekan kavramı (Köksal, 2015, s. 7) filmde sinematografik unsurlarla desteklenerek, izleyici hikayenin akışına dahil edilmiştir. Kamera hareketleri, kaydırmalar ve dinamik kurgu gibi unsurların mekânsal algıyı güçlendirdiği ve hikâyenin akışıyla uyumlu olarak ilerlemesine katkıda bulunduğu söylenebilir. Böylelikle seyirci kendini hikâyenin bir parçası olarak algılamakta ve filme olan ilgisi artmaktadır.

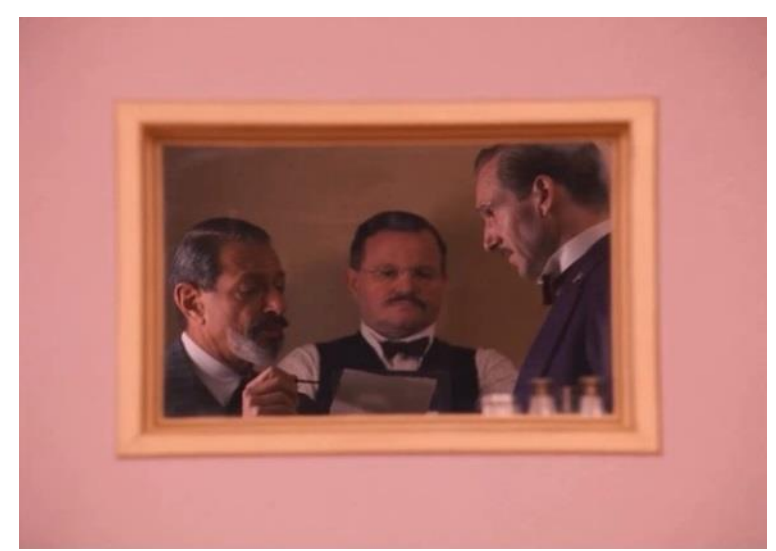

Görsel 4.

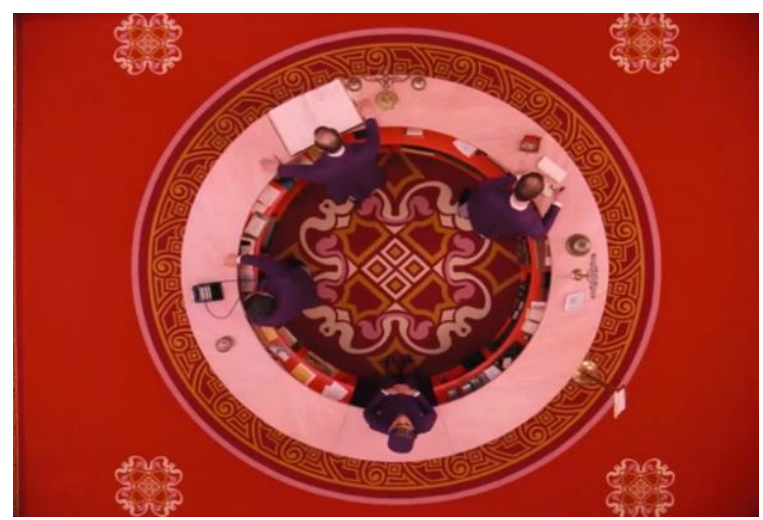

Görsel 5. 
Güngör'e (2005) göre boşluk ve doluluk, varlık ve yokluk gibi kavram çiftleri bu ilişkiden doğar. Görsel sanatların temsili evreninde "boş" ve "dolu" alanlar vardır ve izleyicinin sanat eseriyle tıpkı dış dünyadaki ilişkiye benzer bir ilişki kurmasına, algılama düzeneğinin temel gereksinimini karşılamaya yararlar. Filmde kuşbakışı çekilen sahneler ile mekânda büyüklük algısı yaratılmış, mekânda doluluk boşluk algısı seyirciye aktarılmıştır. Özellikle 1932 ve 1968 yılları arasındaki en büyük farklardan biri olan otelin kullanım yoğunluğu bu sahneler ile pekiştirilmiştir ( Bkz. Görsel 5).

İki savaş arası dönemin (İkinci Dünya Savaşı öncesi) yansıtıldığı 1932 yılı kamera açıları, kaydırmalar ve kuşbakışı çekilen sahnelerle adeta hareket eden mekân algısı yaratılarak o dönemde otelin canlılığına ve popülerliğine vurgu yapılmıştır. Otelin eski canlılığını yitirdiği 1968 yılına ait sahneler ise, boşluk algısının izleyiciye aktarılması ve boşluk algısının yaratılması için sinematografik açıdan daha durağan teknikler kullanılmıştır.

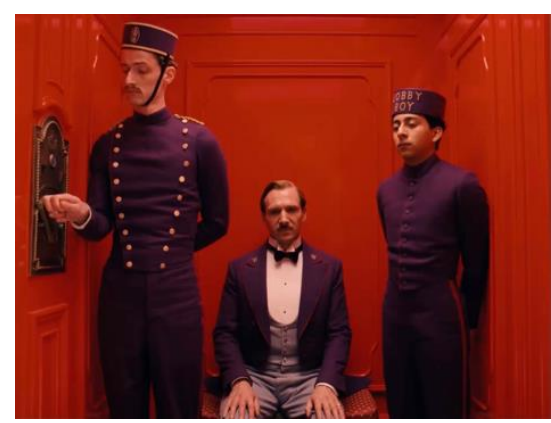

Görsel 6.

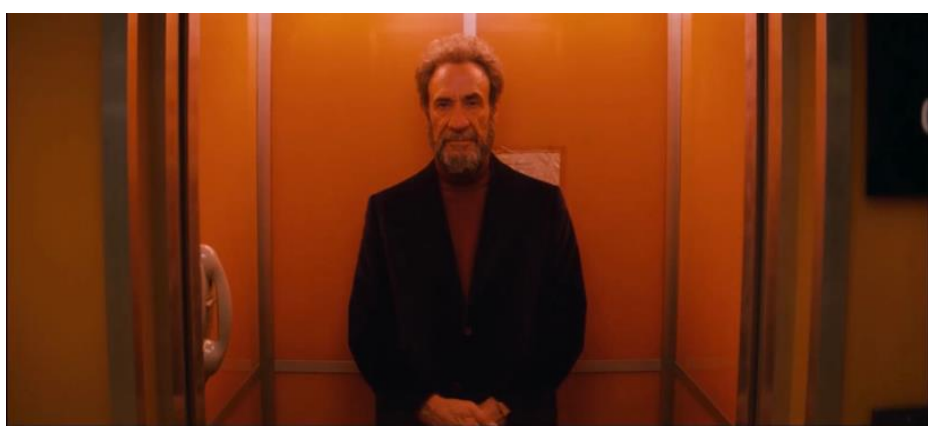

Görsel 7.

Kullanılan renklere bakıldığında ise, yine 1932 yılına ait otel mekânları ile 1968 yılına ait otel mekânları değişiklik göstermektedir. 1932 yılına ait otel mekânlarında canlı ve pastel renkler kullanılırken, 1968 yılına ait otel mekânlarında ise daha koyu tonlar kullanılarak otelin artık eskisi gibi canlı günlerinde olmadığı vurgusu yapılmıştır. Asansör içerisinde 1932 yılında kırmızı renk tercih edilerek canlılık vurgusu yapılmış, ayrıca karakterlerin kıyafetleri de mor renk kullanılarak o canlılık desteklenmiştir. Fakat 1968 yılında aynı asansör içerisinde turuncu ve karakterde siyah renk olduğu görülmektedir (Bkz. Görsel 6 -7).

Restaurant mekânında ise hem 1932 yılında hem de 1968 yılında aynı renk tonları kullanılmıştır. 1932 yılında daha kalabalık, karmaşık ve dağınık bir görüntü sergilerken, 1968 yılında ise daha düzenli fakat insan sayısının az olduğu gözlemlenmektedir. Restaurant mekânının çekimlerinde yine mekân algısını sağlayacak yükseklik ve mekânın büyüklüğüne vurgu yapılmıştır (Bkz. görsel 8).

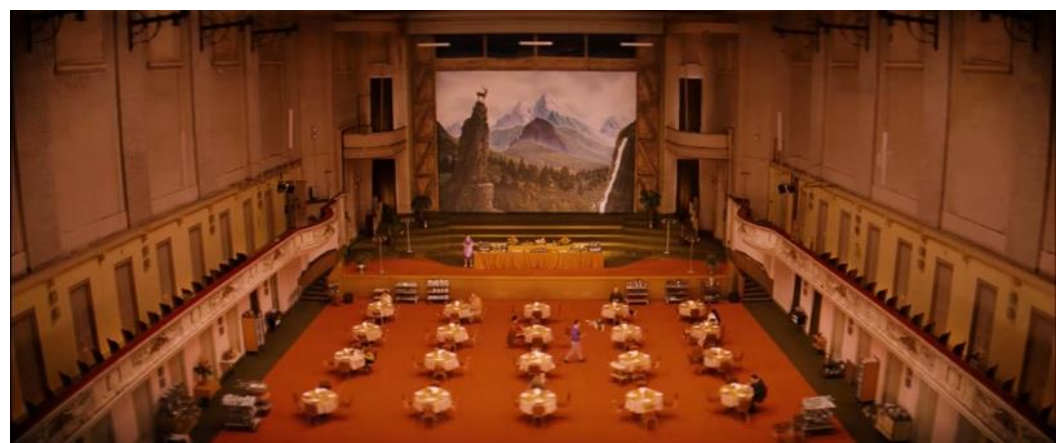

Görsel 8.

Hapishane sahneleri için oldukça ağırlıklı olarak gri tonlar kullanılmış, hapishanenin kötü bir mekân olduğu vurgusu yapılmıştır (Bkz. Görsel 9 ). Mekân tasarımında renklerin de önemi büyüktür. Filmdeki hapishane sahnelerine bakıldığında, mekânları oldukça dar ve kasvetli gösteren renk tonlarının ağırlıkta olduğu görülmektedir. Gri renklerin yoğun olarak kullanımı, izleyicide psikolojik olarak belirsizlik duygusu yaratmaktadır. 


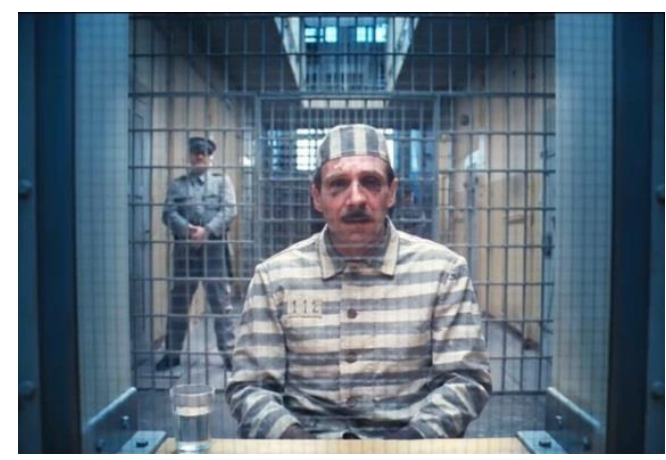

Görsel 9

Gustava'nın odası, beklentilerin aksine gayet yalın bir şekilde tasarlanmış ve oldukça mütevazi küçük bir mekan olarak yorumlanmıştır. Aslında karakter ile ilgili beklenti tam tersine gösterişli ve sosyal statü göstergesi olarak kullanılacağı düşünülmektedir. Yine aynı şekilde 1932'deki Mustafa karakterinin odası yalın ve sade döşenmiş, özensiz ve sosyo-ekonomik sınıfını yansıtacak şekilde tasarlanmıştır. 1968 yılının yansıtıldığı sahnelerde de Mustafa'nın odası yine yalın, otel sahibi olmasına rağmen gösterişten ve zenginlikten uzak bir şekilde tasarlandığ 1 dikkat çekmektedir (Bkz. Görsel 10 11). Mekânsal açıdan değerlendirildiğinde, filmde otelin gösterişli mekanlardan oluşmasına karşın, tüm otelin işletmesini üstlenen ve neredeyse patron gibi davranan Gustava karakterinin odasının sadeliği dikkat çekmektedir. Sinemada mekân algısı yaratma bakımından değerlendirildiğinde, filmde oluşturulan mekanların sınıfsal farklılıkları da vurgulayacak şekilde tasarlandığı görülmektedir.

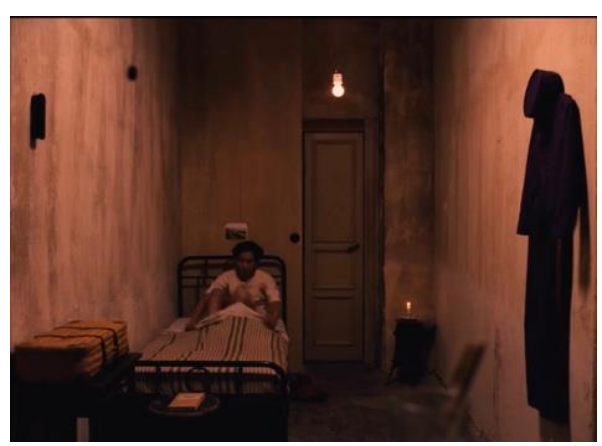

Görsel 10.

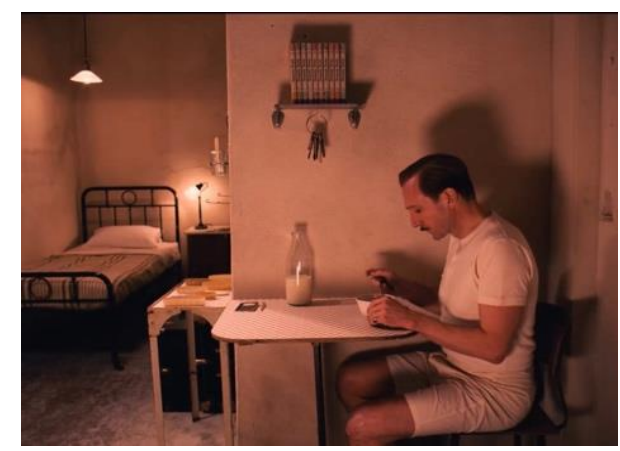

Görsel 11.

\subsection{Sinemada Mekân Tasarımının Öyküyle Olan Uyumu}

Büyük Budapeşte Oteli, konumlandığı mekân olarak 1ssız bir alan hayal edilerek tasarlanmıştır. Otelin bulunduğu kasaba ve kasabanın konu olduğu sahneler kimsenin olmadığı ve terkedilmiş izlenimi veren sahneler olarak sunulmuştur (Bkz Görsel 12). Mekan olgusu açısından değerlendirildiğinde, boşluk duygusunun hakim olduğu söylenebilir. 1932 yılının yansıtıldığı sahneden alınan görselde de görüldüğü gibi otel dışındaki her yer ıssız ve boştur. Burada otelin bir hayal ürünü olduğu izlenimi yaratılmış ve mekânların da muazzamlığı ve uyumu da göz önünde bulundurulduğunda otel dışında hiçbir yerde yaşam izleniminin olmadığı hissi uyandırılmıştır.

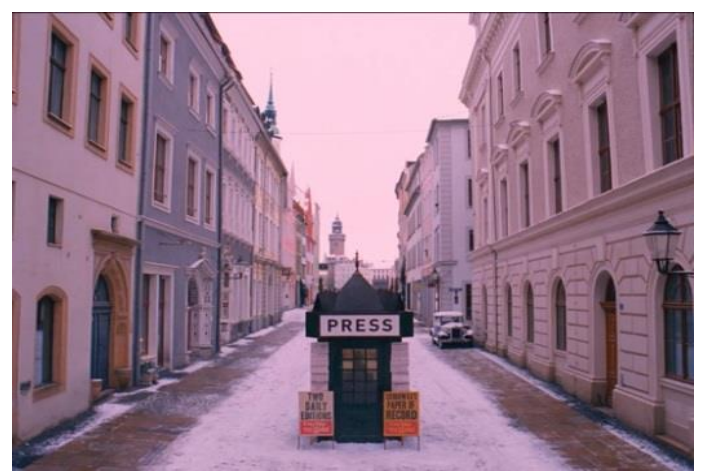

Görsel 12.

83 | $\mathrm{P}$ a g e

www.iiste.org 
Otel 1932 yılında gerek mekan renkleri gerekse diş cephe renkleri ile canlı ve aktif olduğu bir döneme vurgu yapılmıştır. Otelin ışıklarının sürekli yanık olması da ayrıca otelde kalan müşterilerin olduğu izlenimi seyirciye aktarılmıştır (Bkz. Görsel 13 -14). İki dönem arasındaki karşılaştırmaya vurgu yapılan filmde, 1968 yılında otelin oldukça ıssız ve aktif olmadığı gözlenmektedir. 1932 yılına ait sahnelerde ise otelin en canlı dönemi olduğu yukarıdaki görselde (Bknz. Görsel 14) de görüldüğü gibi tüm ışıkların yandığı sahne ile vurgulanmıştır.

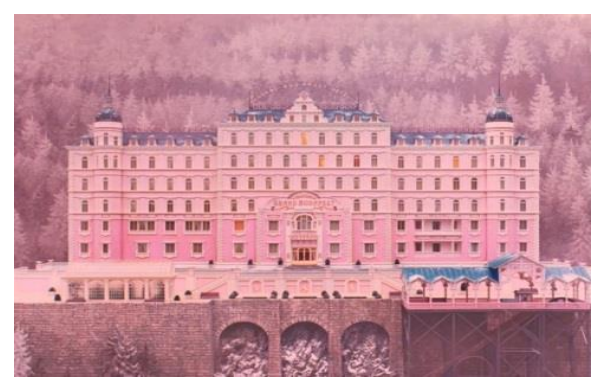

Görsel 13.

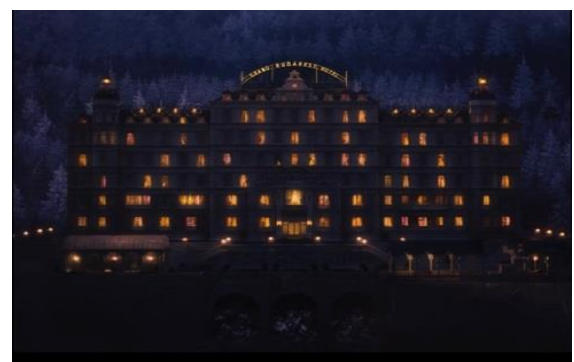

Görsel 14.

1968 yılında ki otelin mekânları ise terk edilmişliği simgeleyecek şekilde koyu tonlarda tasarlanmıştır. Ayrıca dış mekânda yine aynı şekilde renk ve daha keskin formlar eklenerek izleyiciye sunulmuştur (Bkz. Görsel 15 ). Renk tonlamalarıyla 1932 yılının masalsı ve pastel tonlarının yerine, mekânların keskin formlarla yansıtılması için koyu renk tonlar kullanılmıştır.

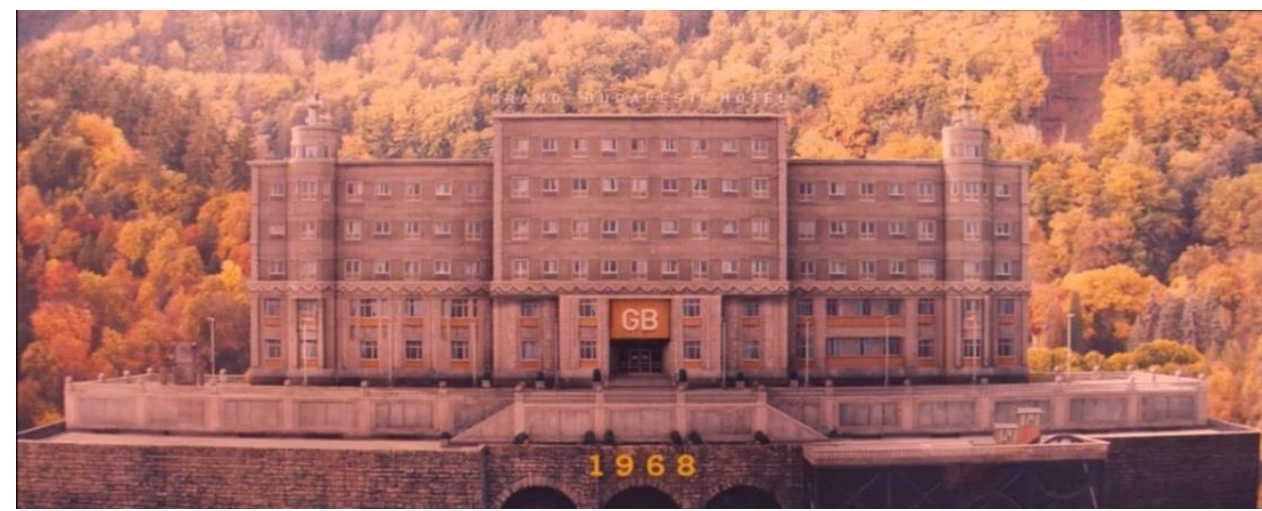

Görsel 15.

Film için hazırlanan mekânlar özellikle 1932 yılına ait görseller masalımsı bir mekânı anlatmakta, kullanılan efektlerle birlikte çizgi film hissi uyandırmaktadır. Böylece hiç var olmayan bir ülkede var olmayan bir otelin kurgusu rahatlıkla izleyiciye aktarılmaktadır. Mekânlar ait oldukları yıllara göre otelin durumunu izleyiciye aktarmakta ve izleyici de algı oluşturmaktadır. Bu nedenle kurgulanan 1932 yılına ait otel ile 1968 yılına ait otel keskin bir çizgi ile birbirinden ayrılmakta ve izleyiciye net bir şekilde aktarılmaktadır.

\subsection{Mimari ve Sinemasal Mekânda Denge, Uyum ve Simetri}

Gerçek fiziki mekânlarda olduğu gibi sinemasal mekânlarda da belirli başlı tasarım kurallarına dikkat edilerek sahne mekanları tasarlanmakta ve izleyiciye o şekilde aktarılmaktadır. The Grand Budapest Hotel (2014) filminde ise bu kurala daha fazla önem verildiği ve mekânların bu kurallara göre dikkatlice tasarlandığı görülmektedir. İç mekânların genel olarak simetrik şekilde tasarlandığ gibi diş mekânında simetrik olarak tasarlandığı görülmektedir ( Bkz. Görsel 16 ve 17 ). 


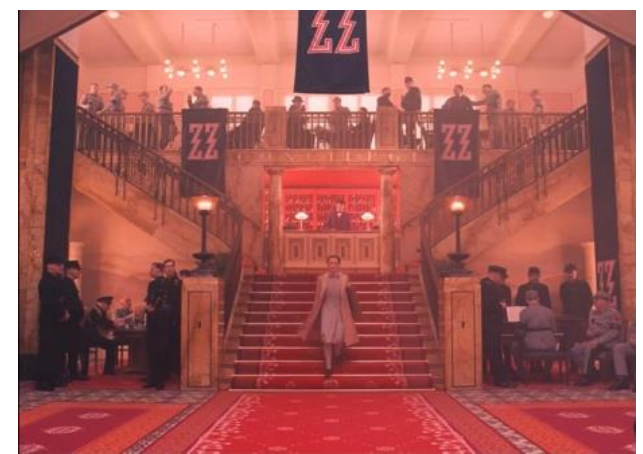

Görsel 16.

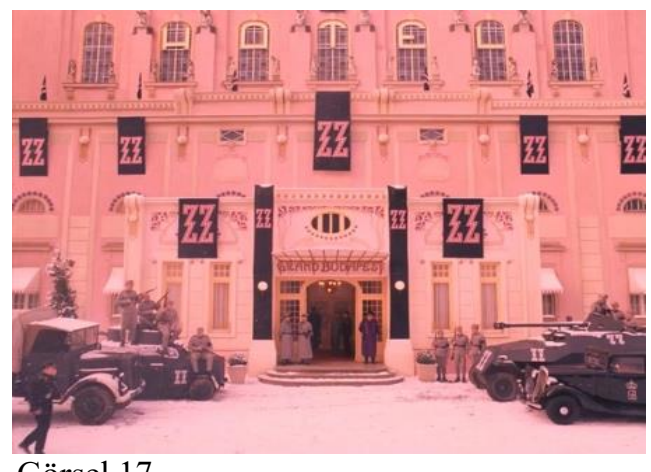

Görsel 17.

Görsel 18 ve 17 de de görebileceği gibi sabit öğelerin simetrik olarak yerleştirilmesi dışında hareketli objelerin ( insan ve araba ) de denge sağlayacak şekilde eşit oranda dağıtıldığı görülmektedir. Böylelikle sahnelerde simetrik bir alg1 yaratılmaktadır. Filmin genelinde simetrik alg1 oluşturulurken, tehlike arz eden veya kötü sahnelerde ise asimetrik bir denge ve düzen oluşturulmuştur.

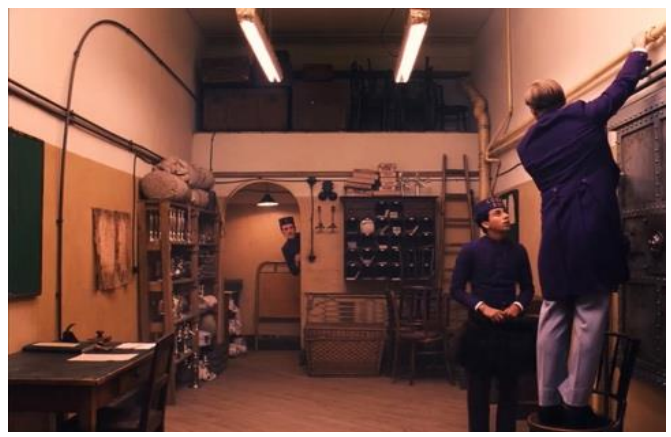

Görsel 18.

\section{Tartışma ve Sonuç}

Sinemanın icadından bu yana karşılıklı etkileşim içinde olan sinema mimarlık, iki ayrı sanat dalı olarak görülse de, iki alanında karşılıklı etkileşimden de öte ortak noktalarının oldukça fazla olduğu görülmektedir. Pallasma'nin (2008) de ifade ettiği gibi "sanatçılar tarafından tasarlanmış mimarlık, zihinsel görüntülerin, hayallerin ve anıların direkt yansımasıdır ve sanatçı kendi zihninde mimarlık yaratır. Gerçek mimarlık ancak unutulmuş anılara ve duygulara ulaşabilirse bireyin ruhuna dokunur." Filmlerde kullanılan sinematografik unsurlar da gerçekliği yeniden inşa ederek, yeniden üreterek, izleyicinin anılarına ve duygularına ulaşan bir sanat dalıdır. Özellikle mekân algısı açısından bakıldığında, izleyicinin zihinsel bir yolculuğa çıkararak tasarlanan sanal ve hayali mekanlarda gezdirir. Bunu yaparken de mimari tasarımlardan yararlanır. Hikaye ile bütünleşen izleyicide tanımlanmış veya tanımlanmamış, gerçek veya sanal bir mekan algısın oluşturur. Araştırma kapsamında incelenen ve özellikle mimari tasarım ve mekân tasarımı ile ön plana çıkan The Grand Budapest Hotel (2014) filminde tasarlanan mekânların sinematografik unsurların (kamera açıları, kamera hareketleri, renk paletleri) da etkisiyle izleyicinin anılarına ve duygularına işaret ettiği görülmektedir. Sinemada mimari ve mekânsal alg1 ve sinematografik unsurların etkisinin incelendiği çalışmada, aşağıdaki bulgulara rastlanmıştır.

Film üç tarihsel döneme ayrılmıştır, fakat olay örgüsü ağırlıklı olarak iki dönemde yani 1932 ile 1968 yılları arasında geçmektedir. II. Dünya Savaşı'ndan önceyi ve sonrayı ele alan filmde, dönemler arasındaki farklılıklar mekân tasarımı ile belirginleştirilmiştir. Avrupa'da Zubrowka adlı hayali bir ülkede yer alan Büyük Budapeşte Oteli'nde (The Grand Budapest) iki dünya savaşı arasında gerçekleşen olayları konu alan filmde, mekân algısı açısından bakıldığında, iki dönem arası (19321968) geçişler kamera hareketleri ile izleyiciye adeta yolculuğa çıkacak hissi vererek kurgulanmıştır.

Sinemada mimari ve mekân tasarımı açısından bakıldığında, sinematografik unsurların da etkisi ile hayali mekânlarda masalsı bir anlatım ile gerçeklik inşa edilmiştir.

Mekân yaratma ve mekân algısı iki ayrı dönemde de farklılıklar göstermektedir. Özellikle asıl hikâyenin ilerlediği savaş öncesi dönemdeki mekân tasarımında her şeyin yolunda olduğu hissi

85 I P a g e

www.iiste.org 
verilmekte ve savaş sonrası anıların anlatıldığı 1968 döneminde ise dağılmış büyüleyiciliğini yitirmiş bir mekân algısı verilmektedir. Her iki dönem de mekân algısı açısından öyküye uygun olarak tasarlanmıştır. Filmde mimari ve sinemasal mekânda denge, uyum ve simetri göze çarpmaktadır. Uyum ve denge ilişkisi açısından mimari ve sinema ilişkisi ön plana çıkmaktadır.

Filmde, mekânlar arasında oluşturulan zıtlıklarla üst sınıf ve alt sınıf arasındaki farklılıkların belirginleştirildiği görülmektedir. Hikâyenin geçtiği otelin en büyüleyici zamanlarının aktarıldığı savaş öncesi dönemde, üst sınıfın kullandığı mekân tasarımı uyumlu, dengeli, geniş ve devasa, renk tonlaması açısından canlı ve büyüleyicidir. Otel çalışanlarına ait mekân tasarımı ise dar sıkışmışlık hissi veren soluk renklerin ağırlıkta olduğu bakımsız mekânlardan oluşmaktadır. Filmde inşa edilmemiş ve gerçeklik düzleminde var olmayan bir sanal mimarlık alanı tanımlaması yapıldığı görülmüştür. Filmde genellikle tekinsizlik, aidiyetsizlik ve yurtsuzluk gibi duyumsamalar ağırlıkta olduğu gibi, filmde temsil edilen karakterlerde de aidiyet duygusunun olmadığı gözlemlenmiş̧ir.

İnsanlık tarihinden bu yana insanların geçmişle bağ kurabilmesi ve aidiyet duygusu oluşturması bakımından mekân algısı büyük bir önem taşımaktadır. İnsanların dünyayı algılama ve yorumlama becerisinin mekân algısı ile gerçekleștiği düşünüldüğünde, filmlerde deneyimlenmiş veya deneyimlenmemiş, tanımlanmış veya tanımlanmamış, gerçek veya hayali mekân tasarımları sinema ve mimarlık alanlarının ortak konusudur.

\section{Kaynakça}

Beşgen, A. ve Köseoğlu, Ş. (2019) Sinema-mimarlık arakesitinde bir mekana dokunmak: Sinetasarım atölyesi, SineFilozofi Dergisi, Özel Sayl, 26-52.

Beşışık, G. (2013). Sinema ve mimarlıkta mekan kurgusu ve kavrayışı, Dokuz Eylül Üniversitesi, Fen Bilimleri Enstitüsü (Yayımlanmamış Yüksek Lisans Tezi), İzmir.

Ersoy, E. (2010). Mimarlık ve Sinema Etkileşimi Bağlamında Mekansal İmge Kullanımıyla Durağan Mekanın Dinamik Mekana Dönüşümü, İstanbul Teknik Üniversitesi, Fen Bilimleri Enstitüsü, Yayımlanmamış Yüksek Lisans Tezi, İstanbul.

Kracauer, S. (2015). Film teorisi: Fiziksel gerçekliğin kurtuluşu, Metis Yayınları, İstanbul.

Kutucu, S. (2005). Transformation of meaning of architectural space in cinema: The cases of "Gattaca" and "Truman show, Doktora Tezi, Fen Bilimleri Enstitüsü, İzmir Yüksek Teknoloji Enstitüsü, İzmir.

Köksal, C. (2015). Göstergebilimsel Yaklașımla Sinemasal Mekân Analizi: Otellerde Geçen Filmler Üzerinden Mekânsal Ve Anlamsal Çözümlemeler, İstanbul Teknik Üniversitesi, Sosyal Bilimler Enstitüsü, Yayımlanmamış Yüksek Lisans Tezi, İstanbul.

Pallasmaa, J. (2008). Sinema ve mimarlı. (Çev. Ilgın Külekçi). Derya Karadağ (Ed.) http://v3.arkitera.com/g143-sinema-ve-mimarlik.html?year=\&aID=2621 Son erişim tarihi: 09.02.2021.

Ricoeur, P. (2012). Hafiza, tarih, unutuş. (Çev. Mehmet Emin Özcan), İstanbul: Metis Yayınları.

Ryan, M., Douglas, K. (2010). Politik kamera, (Çev. Elif Özsayar), Ayrıntı Yayınları, İstanbul.

Öztürk, M. (2007). Sine-masal kentler: modernitenin iki kahramanı kent ve sinema üzerine bir inceleme, Donkişot Yayınları, İstanbul.

Öztürk, S. (2012). Mekan ve iktidar: Filmlerle iletişim mekanlarının altpolitikası, Phoenix Yayınevi, Ankara.

Zizek, S. (2010). Sunuş: Toplumsalın kalbindeki film, filmlerle sosyoloji içinde, Bülent Diken ve Carsten B. Laustsen, (Çev. Sona Ertekin), Metis Yayınları, İstanbul. 